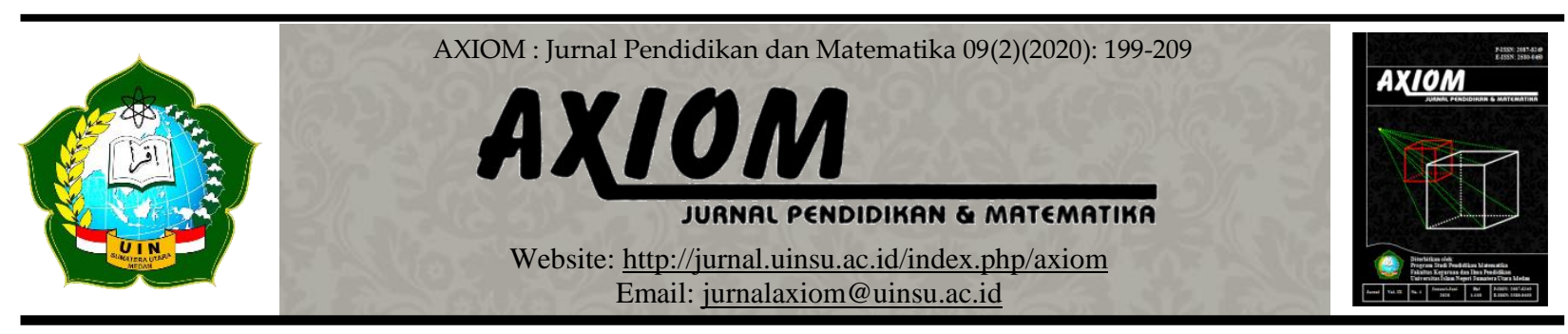

\title{
PENGARUH PENGGUNAAN MODEL PEMBELAJARAN KOOPERATIF TIPE JIGSAW TERHADAP HASIL BELAJAR MAHASISWA
}

\author{
Oleh:
}

\author{
Riri Syafitri Lubis \\ Matematika, Fakultas Sains dan Teknologi, Universitas Islam Negeri Sumatera Utara \\ E-mail: riri_syafitri@uinsu.ac.id \\ doi : 10.30821/axiom.v9i2.8735
}

\begin{abstract}
Abstrak:
Tujuan penelitian ini adalah untuk mengetahui pengaruh penggunaan model pembelajaran kooperatif tipe jigsaw terhadap hasil belajar aljabar linier mahasiswa. Adapun populasi dalam penelitian ini adalah seluruh mahasiswa semester III Program studi Fisika, Fakultas Sains dan Teknologi, Universitas Islam Negeri Sumatera Utara. Sedangkan sampel dalam penelitian ini adalah mahasiswa Fis 1 semester III yang berjumlah 38 mahasiswa. Penelitian ini menggunakan metode experimental design dengan jenis pretest dan posttest one group design. Penelitian ini mengambil desain eksperimen yang hanya melibatkan satu kelompok tanpa kelompok pembanding. Dari hasil penelitian diperoleh bahwa $\mathrm{F}_{\text {hitung }}>\mathrm{F}_{\text {tabel }}$ yaitu 55,53>4,11 maka persamaan garis regresi tersebut menunjukkan signifikan dan dapat disimpulkan bahwa terdapat terdapat pengaruh model pembelajaran koperatif tipe jigsaw terhadap hasil belajar aljabar linier mahasiswa semester III Program studi Fisika, Fakultas Sains dan Teknologi, Universitas Islam Negeri Sumatera Utara.
\end{abstract}

Kata Kunci:

Model Pembelajaran Kooperatif Tipe Jigsaw, Hasil Belajar, Aljabar Linier

\section{Abstract:}

The purpose of this study was to determine the effect of using the type of jigsaw cooperative learning model on student linear algebra learning outcomes. The population in this study were all third semester students of Physics Study Program, Faculty of Science and Technology, State Islamic University of North Sumatra. While the sample in this study were 38 students of the third semester of Fiscal 1. This study used experimental design with the type of pretest and posttest one group design. This study took an experimental design involving only one group without a comparison group. From the results of the study, it was found $F_{\text {count }}>F_{\text {table }}$ that $55.53>4.11$, the regression line equation shows significant and it can be concluded that there is an effect of the jigsaw cooperative learning model on the learning outcomes of the third semester students of the Physics Study Program, Faculty of Science and Technology, State Islamic University of North Sumatera.

\section{Keywords:}

Jigsaw Type Cooperative Learning Model, Learning Outcomes, Linear Algebra 


\section{A. Pendahuluan}

Usaha manusia untuk mengembangkan kemampuan dan kepribadian individu baik di dalam maupun di luar dirinya ditempuh melalui pendidikan. Tujuan pendidikan adalah mencerdaskan kehidupan bangsa dan mengembangkan manusia seutuhnya yaitu manusia yang memiliki pengetahuan dan keterampilan kesehatan jasmani dan rohani, kepribadian yang mantap dan mandiri serta rasa tanggung jawab. Pendidikan merupakan suatu proses pembentukan jiwa manusia agar dapat tumbuh dan berkembang sesuai dengan potensi dan kemampuan serta kemauan yang ada pada diri manusia. Hamid dalam tulisan Harleni dan Susilawati (2018) menyatakan bahwa peningkatan kualitas pendidikan menunjukkan pada upaya peningkatan kualitas proses dan hasil pembelajaran.

Perguruan tinggi merupakan lembaga formal yang bertugas menciptakan kesempatan kepada mahasiswa untuk mengembangkan potensinya. Belajar dan mengajar adalah dua proses yang mempunyai hubungan sangat erat dalam dunia pengajaran. Biasanya belajar dikhususkan kepada mahasiswa dan mengajar pada dosen, sekalipun keduanya dapat melakukan kedua hal itu yaitu baik belajar maupun mengajar atau dengan perkataan lain saling belajar dan saling mengajar. Menurut teori konstruktivis, satu prinsip yang paling penting dalam psikologi pendidikan adalah bahwa pengajar (dosen) tidak hanya sekadar memberikan pengetahuan kepada mahasiswa. Mahasiswa harus membangun sendiri pengetahuannya. Dosen dapat memberikan kemudahan untuk proses ini, dengan memberi kesempatan mahasiswa untuk menemukan atau menerapkan ide-ide mereka sendiri (Trianto, 2007). Walaupun mahasiswa telah difokuskan pada satu jurusan, namun kenyataannya, masih ada mahasiswa yang lemah dalam perkuliahan, khususnya matakuliah matematika.

Berdasarkan pengamatan peneliti di Program studi Fisika, Fakultas Sains dan Teknologi, Universitas Islam Negeri Sumatera Utara, bahwa masih banyak mahasiswa yang mengalami kesulitan dalam mengerjakan soal-soal perkuliahan khususnya mata kuliah aljabar linier. Hal ini sejalan dengan tes yang telah diberikan kepada mahasiswa semester III Program studi Fisika, Fakultas Sains dan Teknologi, Universitas Islam Negeri Sumatera Utara pada mata kuliah aljabar linier. Hanya 15\% mahasiswa yang dapat menjawab dengan benar dan 35\% mahasiswa mengarah kepada jawaban yang benar, sedangkan 50\% mahasiswa sama sekali tidak dapat menyelesaikan soal tersebut. Hal ini menunjukkan bahwa mata kuliah aljabar linier merupakan salah satu mata kuliah yang masih sulit dipahami oleh mahasiswa. Berdasarkan hasil observasi yang dilakukan oleh peneliti tentang hasil belajar pada mata kuliah aljabar linier dengan menggunakan pembelajaran yang bersifat konvensional, bahwa hasil belajar mahasiswa semester III Fisika masih rendah. Dalam pembelajaran yang berlangsung dosen bertindak sebagai pemberi informasi sedangkan mahasiswa sebagai penerima. Akibatnya mahasiswa kurang memahami informasi dan tidak mampu menggunakan informasi yang ada pada saat diberikan pertanyaan (soal-soal).

Berhasil tidaknya tujuan yang akan dicapai tergantung kepada penggunaan model yang tepat. Suatu model yang baik adalah model yang menemukan sendiri suatu pola atau struktur atas bimbingan dosen, karena dengan metode yang relevan terhadap suatu materi pelajaran dan keterlibatan mahasiswa secara aktif dalam interaksi belajar mengajar akan meningkatkan hasil belajar mahasiswa. Sadirman (2006) menyatakan bahwa hasil belajar akan optimal kalau ada motivasi dan motivasi dapat berfungsi sebagai pendorong usaha dan pencapaian prestasi. Dalam kegiatan belajar, maka motivasi dapat dikatakan sebagai keseluruhan daya penggerak dalam diri mahasiswa yang menimbulkan kegiatan belajar, yang menjamin kelangsungan dari kegiatan belajar, sehingga yang dikehendaki oleh subyek belajar itu dapat tercapai.

Ketidaktepatan dosen dalam merancang dan melaksanakan pembelajaran menjadi salah satu faktor penyebab prestasi belajar mahasiswa masih rendah. Kesulitan mahasiswa dalam mengikuti perkuliahan di kampus, dikarenakan mahasiswa menganggap mata kuliah yang diajarkan sulit dan membosankan, juga disebabkan oleh dosen yang kurang tepat merancang dan melaksanakan pembelajaran di kelas. Oleh sebab itu, pembelajaran perlu dilakukan sedemikian rupa sehingga mahasiswa mendapat kesempatan mengembangkan kecerdasannya yang dominan 
secara optimal. Dosen sebagai salah satu komponen yang menentukan proses belajar mengajar harus mampu mendayagunakan model atau cara mengajar yang lebih menjamin keberhasilan proses belajar mengajar. Sehingga perlu alternatif pembelajaran yang dapat meningkatkan hasil belajar.

Pembelajaran koperatif tipe jigsaw merupakan suatu proses yang sistematis yang mengisyaratkan adanya orang yang mengajar dan belajar dengan didukung komponen lainnya, seperti fasilitas belajar mengajar. Pada model pembelajaran koperatif tipe jigsaw, terdapat kelompok asal dan kelompok ahli. Kelompok asal yaitu kelompok induk mahasiswa yang beranggotakan mahasiswa dengan kemampuan, asal, dan latar keluarga yang beragam. Kelompok ahli yaitu kelompok mahasiswa yang terdiri dari anggota kelompok asal yang berbeda. Dalam proses tersebut, terdapat kegiatan memilih, menetapkan, dan mengembangkan untuk mencapai hasil pembelajaran yang diinginkan. Untuk itu, peneliti tertarik untuk mengetahui pengaruh penggunaan model pembelajaran koperatif tipe jigsaw terhadap hasil belajar aljabar linier pada mahasiswa semester III Program studi Fisika, Fakultas Sains dan Teknologi, Universitas Islam Negeri Sumatera Utara.

\section{B. Kajian Teoritis \\ 1. Hasil Belajar}

Belajar adalah sebuah proses perubahan di dalam kepribadian manusia dan perubahan tersebut di tampakkan dalam bentuk peningkatan kualitas dan kuantitas tingkah laku seperti peningkatan kecakapan, pengetahuan, sikap, kebiasaan, pemahaman, keterampilan, daya pikir, dan kemampuan-kemampuan yang lain. Belajar merupakan proses dasar perkembangan hidup manusia. Dengan belajar, manusia melakukan perubahan-perubahan kualitatif individu sehingga tingkah lakunya berkembang. Sedangkan hasil adalah suatu istilah yang digunakan untuk menunjukkan sesuatu yang dicapai seseorang setelah melakukan suatu usaha. Jika dikaitkan dengan belajar berarti hasil menunjukkan sesuatu yang dicapai oleh seseorang yang belajar. Suryabrata (2002) berpendapat bahwa hasil belajar adalah kemampuan yang diperoleh setelah menerima pengalaman belajar, dapat dinyatakan dengan angka dan di ukur dengan menggunakan tes hasil belajar.

Untuk mengetahui perkembangan sampai dimana hasil yang telah dicapai oleh seseorang dalam belajar, maka harus dilakukan evaluasi. Hasil evaluasi merupakan hasil belajar bagi mahasiswa dalam proses pembelajaran. Hasil belajar dipandang secara umum sebagai perwujudan nilai-nilai yang diperoleh mahasiswa melalui proses belajar mengajar. Hal yang mempengaruhi hasil belajar mahasiswa yaitu peran seorang dosen dalam menyampaikan materi pelajaran dapat mempengaruhi hasil belajar mahasiswa.

Ada dua faktor utama yang mempengaruhi hasil belajar mahasiswa, yakni faktor dari dalam diri mahasiswa dan faktor yang datang dari luar diri mahasiswa, terutama kemampuan yang dimilikinya. Faktor kemampuan mahasiswa besar sekali pengaruhnya terhadap keberhasilan belajar mahasiswa. Disamping faktor kemampuan yang dimiliki oleh mahasiswa, juga ada faktor lain seperti motivasi belajar, ketekunan, sosial ekonomi, faktor fisik dan dan psikis. Menurut Muhibbin (2010) bahwa hasil belajar adalah bila seseorang telah belajar akan terjadi perubahan tingkah laku pada orang tersebut, misalnya dari tidak tahu menjadi tahu, dan dari tidak mengerti menjadi mengerti. Berdasarkan teori taksonomi bloom hasil belajar dalam rangka studi dicapai melalui tiga kategori ranah, dua diantaranya adalah kognitif dan afektif.

Dari definisi di atas dapat disimpulkan bahwa hasil belajar adalah hasil yang dicapai dalam bentuk angka-angka atau skor setelah diberikan tes hasil belajar pada setiap akhir pembelajaran. Nilai yang diperoleh mahasiswa menjadi acuan untuk melihat penguasaan mahasiswa dalam menerima materi pembelajaran.

\section{Model Pembelajaran Koperatif Tipe Jigsaw}

Model pembelajaran kooperatif tipe jigsaw adalah sebuah model belajar kooperatif yang menitikberatkan pada kerja kelompok kecil. Pembelajaran koperatif tipe jigsaw mengisyaratkan 
adanya orang yang mengajar dan belajar dengan didukung komponen lainnya. Setiap anggota kelompok bertanggung jawab untuk mengajari anggota-angota lain tentang salah satu bagian materi dan menjadi pakar dibagiannya (Pangesti, 2017).

Menurut pendapat Nasution (2004) menyatakan bahwa model pembelajaran Jigsaw adalah teknik pembelajaran kooperatif dimana mahasiswa, bukan dosen, yang memiliki tanggung jawab lebih besar dalam melaksanakan pembelajaran. Tujuan dari jigsaw ini adalah mengembangkan kerja tim, keterampilan belajar kooperatif dan menguasai pengetahuan secara mendalam yang tidak mungkin diperoleh apabila mereka mencoba untuk mempelajari semua materi sendirian. Model pembelajaran jigsaw adalah model belajar kooperatif dengan cara mahasiswa belajar dalam kelompok kecil yang terdiri atas empat sampai enam orang secara heterogen, dan mahasiswa bekerjasama, saling ketergantungan positif dan bertanggung jawab secara mandiri. Pada kegiatan pembelajaran kooperatif tipe jigsaw, permasalahan yang dihadapi setiap kelompok sama disebut sebagai tim ahli.

Tujuan utama dalam penerapan model pembelajaran kooperatif adalah agar mahasiswa dapat belajar secara berkelompok bersama teman-temannya dengan cara saling menghargai pendapat yang disampaikan. Adapun langkah-langkah model pembelajaran kooperatif tipe jigsaw adalah: (a) Mahasiswa dibagi ke dalam beberapa kelompok dengan anggota 4 sampai dengan 6 orang. (b) Dosen menginformasikan, setiap mahasiswa dalam tim memiliki materi dan tugas yang sama. (c) Dosen mengelompokkan dari anggota tim yang berbeda dengan penugasan yang sama namun membentuk kelompok baru (kelompok ahli). (d) Setelah kelompok ahli berdiskusi, kelompok ahli ini kemudian kembali ke kelompoknya semula dan kemudian menjelaskan kepada anggota kelompoknya tentang materi yang sudah didiskusikan namun hanya pada materi yang mereka kuasai. (e) Dosen mengajak mahasiswa tiap tim ahli untuk mempersentasikan hasil diskusinya. (f) Dosen mengulas materi dengan tujuan agar pemahaman mahasiswa lebih jelas. (g) Dosen bersama mahasiswa melakukan penyimpulan materi serta menutup pelajaran.

Setiap dalam model pembelajaran pasti memiliki keunggulan dan kelemahan. Berikut beberapa keunggulan dari model pembelajaran kooperatif tipe jigsaw yaitu: (a) Mempermudah pekerjaan dosen dalam mengajar, karena sudah ada tim ahli yang bertugas menjelaskan materi kepada rekan-rekannya. (b) Pemerataan materi dapat dicapai dalam waktu yang singkat. (c) Melatih mahasiswa untuk berbicara dan berpendapat.

Proses belajar mengajar menggunakan model pembelajaran kooperatif tipe jigsaw membutuhkan waktu yang lebih lama apalagi bila penataan ruang belum terkondisi dengan baik, sehingga perlu waktu merubah posisi yang dapat juga menimbulkan gaduh serta butuh waktu dan persiapan yang matang sebelum model pembelajaran ini bisa berjalan dengan baik. Teori yang melandasi model pembelajaran kooperatif tipe jigsaw yaitu teori pembelajaran sosial Vygotsky. Teori Vygotsky ini, lebih menekankan pada aspek sosial dari pembelajaran. Menurut Vygotsky bahwa proses pembelajaran akan terjadi jika mahasiswa bekerja atau menangani tugas-tugas yang belum dipelajari, namun tugas-tugas tersebut masih berada dalam jangkauan mereka. Vygotsky yakin bahwa fungsi mental yang lebih tinggi pada umumnya muncul dalam percakapan dan kerja sama antar-individu sebelum fungsi mental yang lebih tinggi itu terserap ke dalam individu tersebut.

Kekurangan model pembelajaran kooperatif tipe jigsaw yaitu: (a) Mahasiswa yang aktif akan lebih mendominasi diskusi, dan cenderung mengontrol jalannya diskusi. Untuk mengantisipasi masalah ini dosen harus benar-benar memperhatikan jalannya diskusi. Dosen harus menekankan agar para anggota kelompok menyimak terlebih dahulu penjelasan dari tenaga ahli. Kemudian baru mengajukan pertanyaan apabila tidak mengerti. (b) Mahasiswa yang memiliki kemampuan membaca dan berpikir rendah akan mengalami kesulitan untuk menjelaskan materi apabila ditunjuk sebagai tenaga ahli. Untuk mengantisipasi hal ini dosen harus memilih tenaga ahli secara tepat, kemudian memonitor kinerja mereka dalam menjelaskan materi, agar materi dapat tersampaikan secara akurat. Mahasiswa yang cerdas cenderung merasa 
bosan. Untuk mengantisipasi hal agar mahasiswa yang cerdas tertantang untuk mengikuti jalannya diskusi.

\section{Metode Penelitian}

\section{Jenis Penelitian}

Penelitian ini menggunakan pendekatan kuantitatif. Metodenya adalah experimental design dengan jenis pretest dan posttest one group design yaitu penelitian eksperimen yang hanya melibatkan satu kelompok tanpa kelompok pembanding.

\section{Waktu dan Tempat Penelitian}

Penelitian ini dilaksanakan di kelas perkuliahan Program studi Fisika, Fakultas Sains dan Teknologi Universitas Islam Negeri Sumatera Utara, khususnya pada mahasiswa semester III. Penelitian ini dilakukan pada semester ganjil tahun akademik 2018/ 2019.

\section{Populasi dan Sampel}

populasi dalam penelitian ini adalah seluruh mahasiswa semester III Program studi Fisika, Fakultas Sains dan Teknologi, Universitas Islam Negeri Sumatera Utara. Sedangkan sampel dalam penelitian ini adalah mahasiswa kelas Fis 1 semester III yang berjumlah 38 mahasiswa.

\section{Prosedur}

Prosedur penelitian yang akan dilakukan oleh peneliti mulai pengumpulan data sampai pengelolaan data dapat dilihat dalam skema pada Gambar 1berikut:

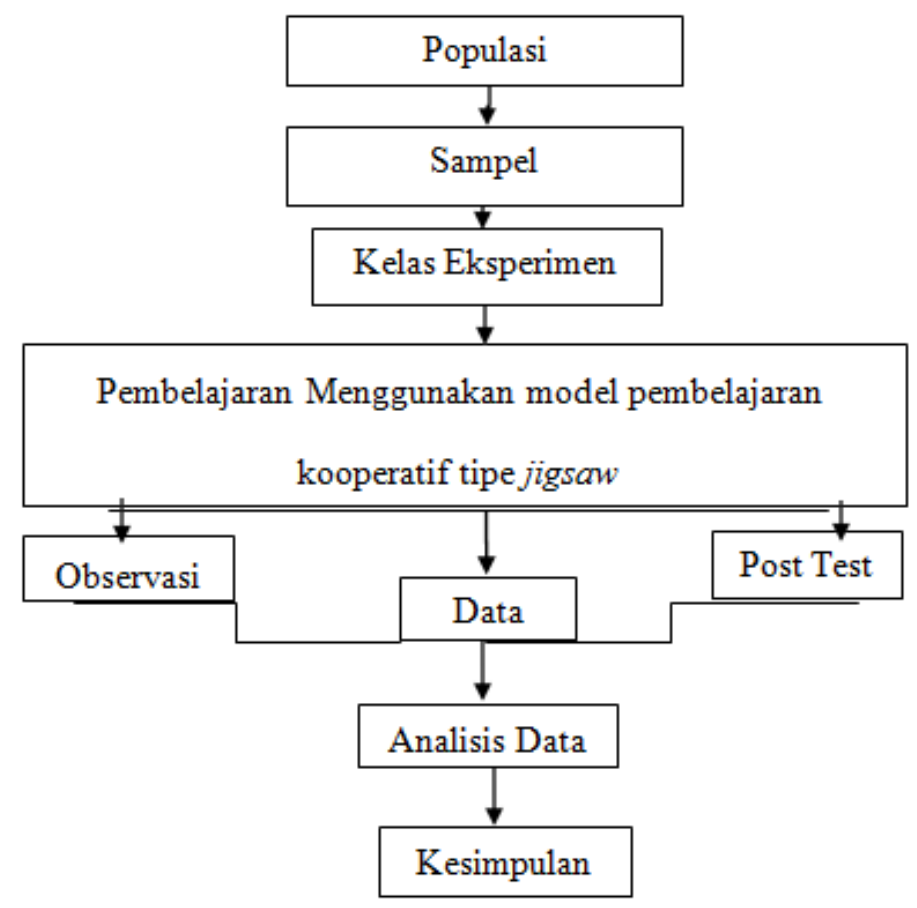

\section{Gambar 1. Skema Prosedur Penelitian}

\section{Hasil Penelitian dan Pembahasan}

\section{Hasil}

Berdasarkan persyaratan analisis, maka sebelum dilakukan pengujian hipotesis, terlebih dahulu dilakukan uji prasyarat analisis. Uji prasyarat yang perlu dipenuhi yaitu berupa uji normalitas dan uji homogenitas. Hasil perhitungan uji normalitas dapat dilihat pada tabel 1 berikut: 
Tabel 1. Rekapitulasi Hasil Perhitungan Uji Normalitas

\begin{tabular}{ccccc}
\hline Data & $\mathbf{L}_{\mathbf{0}}$ & $\mathbf{L}_{\text {tabel }}$ & Kesimpulan & Ket \\
\hline Pretest & 0.1493 & 0.1519 & Terima $\mathrm{H}_{0}$ & Normal \\
Posttest & 0.1278 & 0.1519 & Terima $\mathrm{H}_{0}$ & Normal \\
\hline
\end{tabular}

Dilihat dari tabel 1 di atas diperoleh harga $L_{\text {hitung }}$ untuk pretest adalah 0,1493 dan $L_{\text {tabel }}$ nya adalah 0,1519 maka $L_{\text {hitung }}<L_{\text {tabel }}(0,1493<0,1519)$ dapat disimpulkan bahwa data pretest berdistribusi normal. Begitu juga untuk hasil posttest adalah 0.1278 dan $L_{\text {tabel }}$ nya adalah 0,1519 maka $L_{\text {hitung }}<L_{\text {tabel }}(0.1278<0,1519)$ dapat disimpulkan bahwa data posttest berdistribusi normal.

Untuk uji homogenitas, kriteria pengujian data sampel adalah homogen jika $F_{\text {hitung }}<\mathrm{F}_{\text {tabel }}$ pada taraf signifikan 5\%. Rekapitulasi hasil perhitungan uji homogenitas dapat dilihat pada tabel 2 berikut:

Tabel 2. Rekapitulasi Hasil Perhitungan Uji Homogenitas

\begin{tabular}{cccc}
\hline Data & $\mathbf{F}_{\text {hitung }}$ & $\mathbf{F}_{\text {tabel }}$ & Kesimpulan \\
\hline Pretest & 1,7003 & 1,7878 & Homogen \\
Posttest & 1,0970 & 1,7878 & Homogen \\
\hline
\end{tabular}

Dari hasil perhitungan uji Homogenitas di atas dapat dilihat bahwa $F_{\text {hitung }}<F_{\text {tabel }}$ dan dapat disimpulkan bahwa data pretest dan posttes sampel adalah homogen.

Setelah data hasil pretest dan posttest terpenuhi untuk uji normalitas dan uji homogenitas, maka dilakukan analisis regresi sederhana. Sebelum analisis regresi digunakan maka diperlukan uji keberartian dan uji linieritas terlebih dahulu. Hasil uji keberartian dan uji linieritas disajikan pada daftar analisis varians (ANAVA) regresi linier sederhana.

Tabel 3. Ringkasan Hasil Analisis Regresi

\begin{tabular}{llllll}
\hline Varians & JK & Db & RJK & F $_{\text {hitung }}$ & F $_{\text {tabel }}$ \\
\hline Total & 198473 & 38 & 198473 & & \\
Regresi(a) & 189151,6 & 1 & 189151,6 & & \\
Regresi(b/a) & 5654,9 & 1 & 5654,9 & 55,53 & 4,1 \\
Sisa & 3666,4 & 36 & 101,84 & & \\
Kekeliruan & 9321,4 & 25 & 847,4 & & \\
Tuna Cocok & $-5654,9$ & 11 & $-226,2$ & $-0,27$ & 2,2 \\
\hline
\end{tabular}

\section{Pembahasan}

Berdasarkan Tabel 1. hasil perhitungan keberartian koefisien regresi diperoleh $F_{\text {reg }}$ sebesar 55,53. Sedangkan $F_{\text {tabel }}$ pada taraf $\propto=0,05$ sebesar 4,11. Dengan demikian dapat dilihat bahwa $\mathrm{F}_{\text {hitung }}>\mathrm{F}_{\text {tabel }}$ yaitu 55,53 $>$ 4,11 maka persamaan garis regresi tersebut menunjukkan signifikan.

\section{E. Simpulan}

Hasil penelitian menunjukan bahwa $\mathrm{F}_{\text {hitung }}>\mathrm{F}_{\text {tabel }}$ yaitu 55,53>4,11 maka persamaan garis regresi tersebut menunjukkan signifikan. Hal ini menunjukkan bahwa terdapat terdapat pengaruh model pembelajaran koperatif tipe jigsaw terhadap hasil belajar aljabar linier mahasiswa semester III Program studi Fisika, Fakultas Sains dan Teknologi, Universitas Islam Negeri Sumatera Utara. 


\section{DAFTAR PUSTAKA}

Harleni, S. \& Susilawati, E. (2018). Efektivitas Penggunaan Model Problem Based Learning Terhadap Kemampuan Pemecahan Masalah Program Linier Dengan Memanfaatkan Software QM Pada Mahasiswa STKIP Budidaya Binjai, Jurnal Serunai Ilmu Pendidikan, 3 (2), 59-65.

Muhibbin, Syah (2010). Psikologi Pendidikan Dengan Pendekatan Baru. Bandung: PT. Remaja Rosdakarya.

Nasution, S. (2004). Berbagai Pendekatan dalam Proses Belajar Mengajar. Jakarta: Bina Aksara.

Pangesti, D.A. (2017). Pengaruh Model Pembelajaran Kooperatif Tipe Jigsaw Terhadap Hasil Belajar IPS Siswa Kelas V SD Negeri 2 Sumberejo Kemiling Bandar Lampung. Skripsi. Universitas Lampung.

Sadirman. (2006). Interaksi dan Motivasi Belajar dan Mengajar. Bandung: Raja Grafindo Persada.

Suryabrata (2002). Psikologi Pendidikan. Jakarta: Raja Grafindo Persada.

Trianto. (2011). Model-model pembelajaran inovartif berorientasi konstruktivis: Konsep, landasan teoretis-praktis dan implementasinya. Jakarta: Prestasi Pustaka Publisher. 